
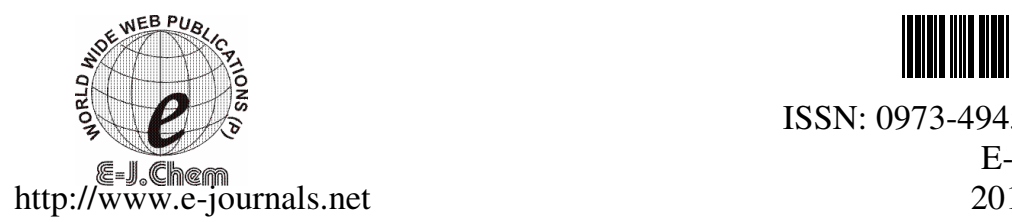

ISSN: 0973-4945; CODEN ECJHAO

E-Journal of Chemistry

2010, 7(S1), S314-S318

\title{
Simultaneous UV Spectrophotometric Determination of Cetrizine and Dextromethorphan in Tablet Dosage Form
}

\author{
R.VIJAYALAKSHMI, S. BHARGAVI and M. D. DHANARAJU* \\ Research lab, GIET School of Pharmacy \\ NH-5 Chaitanya Nagar, Rajahmundry-533294, India \\ mddhanaraju@yahoo.com
}

Received 30 January 2010; Accepted 4 April 2010

\begin{abstract}
Two accurate, precise, sensitve and economical procedures for simultaneous estimation of cetrizine and dextromethorphan in tablet dosage forms have been developed. First method employs formation and solving of simultaneous equations using $230 \mathrm{~nm}$ and $280 \mathrm{~nm}$ as two analytical wavelengths for both drugs in methanol. The second method is $Q$-analysis based on measurement of absorptivity at $224 \mathrm{~nm}$ (as isobestic point) and $280 \mathrm{~nm}\left(\lambda_{\max }\right.$ of CTZ). Cetrizine and dextromethorphan at their respective $\lambda_{\max }$ $280 \mathrm{~nm}$ and $230 \mathrm{~nm}$ and at $224 \mathrm{~nm}$ (isobestic point) shows linearity in a concentration range of $10-30 \mathrm{mcg} / \mathrm{mL}$ for both the drugs. The recovery studies confirmed accuracy of the proposed methods and low values of standard deviation confirmed precision of the methods. The methods were validated as per ICH guidelines.
\end{abstract}

Keywords: Cetrizine, dextromethorphan, Simultaneous-equations method, $Q$-analysis.

\section{Introduction}

Cetrizine hydrochloride is a piperazine derivative and its chemical name is $( \pm)-[2-[4-[(4-$ chlorophenyl) phenyl methyl]-1-piperazinyl]ethoxy]acetic acid, dihydrochloride. It is a nonsedating antihistamine or histamine $(H-1)$ receptor blockers. The mechanism of action of CT is block the ability of histamine to promote the allergic reactions in the body. Cetrizine is used in the treatment of perennial and seasonal allergetic rhinitis and also for chronic urticaria. Few methods have been used for quantitative determination of cetrizine. These methods include fluorimetry ${ }^{2}$, spectrophotometry ${ }^{1,3-8}$, titrimetry and conductimetry ${ }^{9}$, gas chromatography ${ }^{10}$, high-performance liquid chromatography ${ }^{8,11-13}$, liquid chromatography ${ }^{14,15}$ and ion-selective electrodes ${ }^{16}$, based on the formation of ion pair complex of cetrizine with tetraphenylborate. 
Dextromethorphan hydrobromide (DEX), [(+) -3-2-6 Methoxy-17-methyl-9 $\alpha, 13 \alpha, 14 \alpha$ morphinan hydrobromide monohydrate] is a cough suppressant used for the relief of nonproductive cough. It has a central action on the cough centre in the medulla. DEX is rapidly adsorbed from the gastro intestinal tract. It is metabolized in the liver and excreted in the urine as unchanged DEX and demethylated metabolites including DEX, which has some cough suppressant activity ${ }^{17}$. Different methods have been reported for the determination of DEX in the bulk drug, in the dosage forms with other drugs in cough cold products and in biological samples which include HPLC ${ }^{18-22}$, the first and second-derivative technique uv spectrophotometry ${ }^{23-26}$, capillary electrophoresis ${ }^{27-29}, \mathrm{GC}^{30-32}, \mathrm{LC}^{33-36}$ and $\mathrm{TLC}^{37-38}$ methods.

\section{Experimental}

Elico UV-Visible spectrophotometer (SL 164) was used for spectral measurements with $1 \mathrm{~cm}$ matched quartz cells.

\section{Method 1}

\section{Employing simultaneous equations using crammer's rule}

Pure drug samples of cetrizine and dextromethorphan were dissolved separately in methanol, so as to give several dilutions of standard in the concentration range of 10 to $30 \mathrm{mcg} / \mathrm{mL}$ for both drugs. All dilutions were scanned in the wavelength range of 200-400 nm.

Two wavelengths selected for the formation of simultaneous equations were $280 \mathrm{~nm}$ $\left(\lambda_{\max }\right.$ of CTZ) and $230 \mathrm{~nm}\left(\lambda_{\max }\right.$ of DXM). Similarly, mixed standard solutions were also used and the drugs showed linearity in the range of $10-30 \mathrm{mcg} / \mathrm{mL}$ for (CTZ) and (DXM). The absorptivities for the two drugs were presented in the Table 1. Figure 1 represents the overlain spectra of both drugs. The method employs solving of simultaneous equations using crammer's rule and matrices. The simultaneous equations formed were

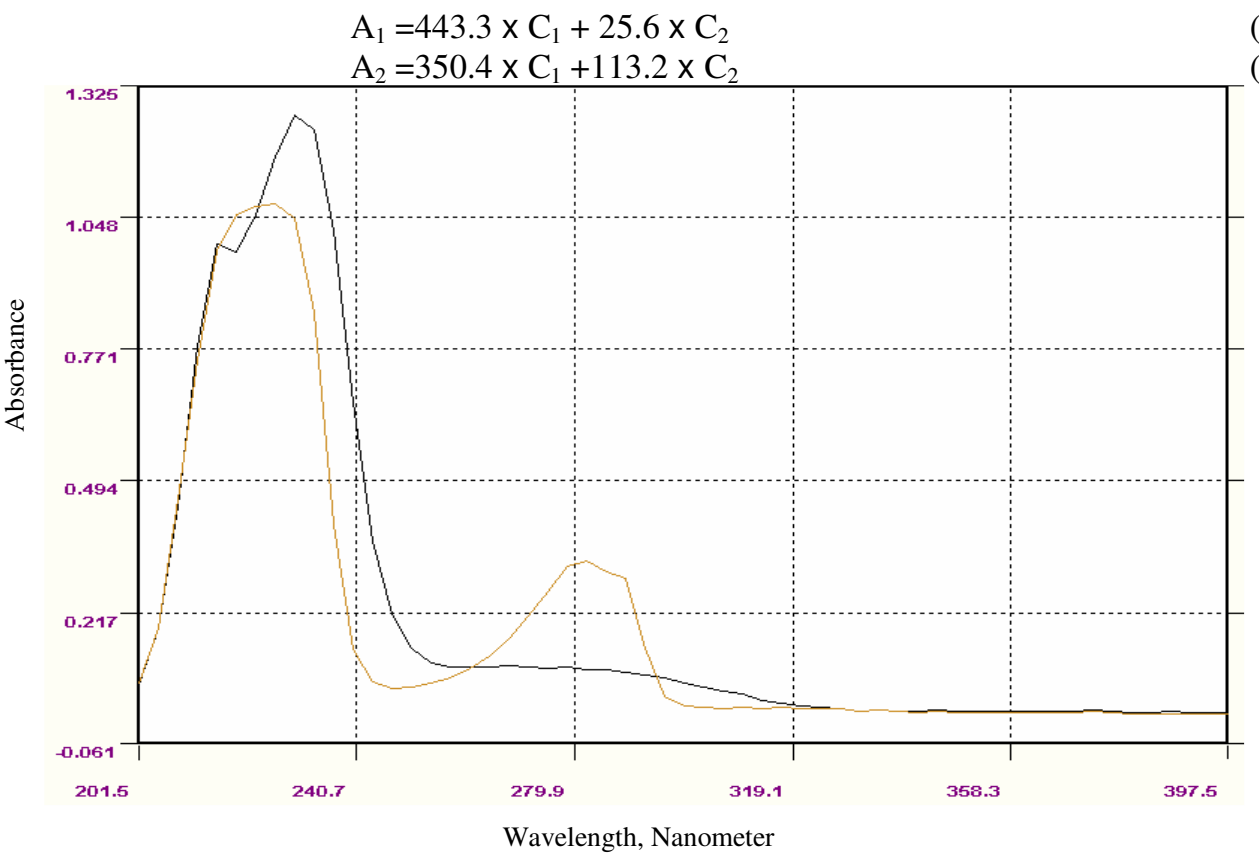

Figure 1. Zero order overlain spectra of CTZ $(10 \mathrm{mcg} / \mathrm{mL})$ and DXM $(10 \mathrm{mcg} / \mathrm{mL})$ 
Where $A_{1}$ and $A_{2}$ are absorbances of sample solution at $230 \mathrm{~nm}$ and $280 \mathrm{~nm}$ respectively. $C_{1}$ and $C_{2}$ are the concentrations of DXM and CTZ respectively in sample solution. By substituting the value of $\mathrm{C}_{1}$ from equation (1) into equation (2), the value of $\mathrm{C}_{1}$ can be obtained. Similarly $\mathrm{C}_{2}$ can also be obtained.

\section{Procedure for analysis of tablet formulation}

The average weight of twenty tablets were determined and then ground to a fine powder. A quantity equivalent to $50 \mathrm{mg}$ of CTZ and $50 \mathrm{mg}$ of DXM were transferred to a $100 \mathrm{~mL}$ volumetric flask. The contents were dissolved by using $50 \mathrm{~mL}$ of methanol, filtered and made up to volume with the same. The solutions were further diluted with methanol to give concentrations of $5 \mathrm{mcg} / \mathrm{mL}$ of CTZ and DXM. Absorbances of these solutions were measured at $280 \mathrm{~nm}$ and $230 \mathrm{~nm}$ as A1 and A2 respectively and concentrations of these two drugs in the sample were calculated using equation (1) and equation (2). Results of the analysis of the tablet formulations were reported in Table 2 . The recovery studies were depicted in Table 3.

\section{Method 2}

\section{Absorbance ratio or q-analysis method}

From the overlain spectrum of CTZ and DXM, two wavelengths were selected, one at $224 \mathrm{~nm}$, isobestic point for both the drugs and the other at $280 \mathrm{~nm}\left(\lambda_{\max }\right.$ of CTZ). The absorbances of the standard and sample solutions were prepared in the same manner as in the previous method. The absorptivities for both drugs at the selected wavelength were presented in Table 1. The method employs Q values; the concentrations of drugs in sample solution were determined by using the following formula. Results of the analysis of the tablet formulations were reported in Table 2. The recovery studies were depicted in Table 3.

$$
\begin{aligned}
& \text { For CTZ } \begin{aligned}
\mathrm{C}_{1}= & \frac{\mathrm{Q}_{0}-\mathrm{Q}_{2}}{\mathrm{Q}_{1}-\mathrm{Q}_{2}} \times \frac{\mathrm{A}}{\mathrm{a}_{1}} \quad \mathrm{C}_{2}=\frac{\mathrm{Q}_{0}-\mathrm{Q}_{1}}{\mathrm{Q}_{2}-\mathrm{Q}_{1}} \times \frac{\mathrm{A}}{\mathrm{a}_{2}} \\
\mathrm{Q}_{0} & =\frac{\text { Absorbance of sample at } 224 \mathrm{~nm}}{\text { Absorbance of sample at } 280 \mathrm{~nm}} \\
\mathrm{Q}_{1} & =\frac{\text { Absorptivity of CTZ at } 224 \mathrm{~nm}}{\text { Absorptivity of CTZ at } 280 \mathrm{~nm}} \\
\mathrm{Q}_{2} & =\frac{\text { Absorptivity of DXM at } 224 \mathrm{~nm}}{\text { Absorptivity of DXM at } 280 \mathrm{~nm}}
\end{aligned}
\end{aligned}
$$

$\mathrm{A}=$ Absorbance of sample at isobestic point $\mathrm{a}_{1}$ and $\mathrm{a}_{2}$-absorptivities of CTZ and DXM respectively at isobestic point.

Table 1. Absorptivity values for cetrizine and dextromethorphan

\begin{tabular}{cccccccc}
\hline \multicolumn{2}{c}{$\begin{array}{c}\text { Concentration } \\
\text { mcg/mL }\end{array}$} & \multicolumn{2}{c}{$\begin{array}{c}\text { Absorptivity at } \\
230\end{array}$} & \multicolumn{2}{c}{$\begin{array}{c}\text { Absorptivity at } \\
\text { 280 nm }\end{array}$} & \multicolumn{2}{c}{$\begin{array}{c}\text { Absorptivity at } \\
224 \mathrm{~nm}\end{array}$} \\
\hline CTZ & DXM & CTZ & DXM & CTZ & DXM & CTZ & DXM \\
\hline 10 & 10 & 350 & 444 & 113 & 26 & 36 & 360 \\
15 & 15 & 350 & 443 & 113 & 26 & 37 & 360.7 \\
20 & 20 & 350.5 & 444 & 114 & 26 & 37.5 & 360.5 \\
25 & 25 & 350.8 & 442 & 113 & 26 & 37.2 & 360.4 \\
30 & 30 & 351 & 443 & 113 & 25 & 38 & 360.7 \\
mean & mean & 350.5 & 443.2 & 113.2 & 25.8 & 37.1 & 360.5 \\
\hline
\end{tabular}


Table 2. Results of commercial formulation analysis

\begin{tabular}{cccc}
\hline Method & $\begin{array}{c}\text { Label Claim, } \\
\text { mg/TAB }\end{array}$ & $\begin{array}{c}\text { \%Label Claim estimated } \\
\text { (Mean } \pm \text { S.D) }\end{array}$ & \% R.S.D \\
\hline I & CTZ, 10 mg & $100.03 \pm 0.550$ & 0.850 \\
& DXM, 10 mg & $99.92 \pm 0.650$ & 0.845 \\
II & CTZ, 10 mg & $99.69 \pm 0.850$ & 0.967 \\
& DXM, 10 mg & $99.58 \pm 0.750$ & 0.958 \\
\hline
\end{tabular}

*Mean of six determinations, R.S.D. is relative standard deviation

Table 3. Recovery studies of CTZ and DXM

\begin{tabular}{|c|c|c|c|c|}
\hline Drug & \multicolumn{2}{|c|}{ Conc. Of drug added } & \multicolumn{2}{|c|}{ \% Recovery ${ }^{*}(($ Mean \pm S.D $)$} \\
\hline \multirow{4}{*}{$\mathrm{CTZ}$} & $\mu \mathrm{g} / \mathrm{mL}$ & $\%$ level & Method I & Method II \\
\hline & 5 & 50 & $99.55 \pm 0.561$ & $99.00 \pm 0.380$ \\
\hline & 10 & 100 & $99.80 \pm 0.489$ & $99.64 \pm 1.001$ \\
\hline & 15 & 150 & $99.61 \pm 0.450$ & $99.98 \pm 0.897$ \\
\hline \multirow{3}{*}{ DXM } & 5 & 50 & $100.09 \pm 0.651$ & $100.38 \pm 0.644$ \\
\hline & 10 & 100 & $101.57 \pm 0.126$ & $99.74 \pm 0.932$ \\
\hline & 15 & 150 & $100.62 \pm 0.345$ & $100.54 \pm 0.659$ \\
\hline
\end{tabular}

\section{Results and Discussion}

The proposed methods for simultaneous estimation of CTZ and DXM in combined dosage forms were found to be simple, accurate, economical and rapid. In both the methods, the values of coefficient of variation were satisfactorily low and recovery was close to $100 \%$ for both the drugs.

\section{Conclusion}

The proposed methods are simple, precise, accurate and rapid for the determination of CTZ and DXM in combined tablet dosage forms. These methods can be adopted as an alternative to the existing spectrophotometric methods. Analysis of authentic samples containing CTZ and DXM showed no interference from the common additives and excipients. Hence, recommended procedure is well suited for the assay and evaluation of drugs in pharmaceutical preparations. It can be easily and conveniently adopted for routine quality control analysis.

\section{References}

1. Rizk N M H and El-Kosasy A M, Egypt J Biomed Sci., 2005, 17, 24.

2. Melwanki M B, Seetharamappa J, Gowda B G and Sajjan A G, Chem Anal., (Warsaw), 2001, 46, 883.

3. Gowda B G, Melwanki M B and Seetharamappa J, J Pharm Biomed Anal., 2001, 25, 1021 .

4. Gazy A A, Mahgoub H, El-Yazbi F A, El-Sayed M A and Youssef R M, J Pharm Biomed Anal., 2002, 30(3), 859-867.

5. Basavaiah K, Latha S and Swamy M J, Talanta, 1999, 50, 887.

6. El-Walily A F M, Korany M A, El-Gindy A and Bedair M F, J Pharm Biomed Anal., 1998, 17, 435. 
7. Ramesh K C, Melwanki M B, Gowda B G, Seetharamappa J and Keshavayya J, Indian J Pharm Sci., 2002, 64, 455.

8. $\quad$ Tam K Y and Quéré L, Anal Sci., 2001, 17, 1203-1208.

9. Youssef A F A and Farghli R A, Canad J Anal Sci Spec., 2006, 51, 288.

10. Baltes E, Coupez R, Brouwers L and Gobert J, J Pharm Biomed Anal., 1988, 74, 149-155.

11. Jaber A M Y, Al-Sherife H A, Al-Omari M M and Badwan A A, J Pharm Biomed Anal., 2004, 36, 341-350.

12. Paw B, Misztal G, Hopkala H and Drozd J, Pharmazie, 2002, 57, 313.

13. Suryanarayana M V, Reddy B P, Krupadanam G L D, Venkatraman S and Sastry C S P, Indian Drugs, 1992, 29, 605.

14. Eriksen H, Houghton R, Green R and Scarth J, Chromatographia, 2002, 55, 145.

15. Zaater M F, Tahboub Y R and Najib N M, J Pharm Biomed Anal., 2000, 22, 739-744.

16. Shoukry A F, Abdel-Ghani N T, Issa Y M and Ahmed H M, Electroanalysis, 1999, 11(6), 443-446.

17. United States Pharmacopoeia, $25^{\text {th }}$ Review, The National Formulary, $19^{\text {th }}$ Review, US Pharmacopoeia, Convention Rockville, MD, 2002.

18. Shervington L A, Anal Lett., 1999, 30, 927.

19. Mistry B, Leslie J, Eddington N E, J Pharm Biomed Anal., 1998, 16(6), 1041-1049.

20. Li Y Q, Tian Z X, Zhao W and Zhu J H, Yaowu FenxiZazhi., 2000, $20,97$.

21. Wilcox M L and Stewart J T, J Pharm Biomed Anal., 2000, 23(5), 909-916.

22. Bendriss E K, Markoglou N and Wainer I W, J Chromatogr B, 2001, 754, 209-215.

23. Tantishaiyakul V, Poeaknapo C, Sribun P and Sirisuppanon K, J Pharm Biomed Anal., 1998, 17(2), 237-243.

24. Ajay S and Piyush T, Indian Drugs, 1999, 36, 444.

25. Gangwal S and Trivedi P, Indian Drugs, 1999, 36, 568.

26. Bratio M S, Kaskhedikar S G and Chaturvedi S C, Indian drugs, 1999, 36, 702-705.

27. Ji S G, Chai Y F, Wu Y T, Liang D S, Xu Z M and Li X, Yaowu FenxiZazhi., 1998, 18, 170.

28. Suntornsuk L, Electrophoresis, 2001, 22, 139-143.

29. Gomez M R, Olsina R A, Martinez L D and Silva M F, J Pharm Biomed Anal., 2002, 30(3), 791-799.

30. Argekar A P, Raj S V and Kapadia S U, Indian Drugs, 1998, 35, 24.

31. Statheropoulos M, Tzamtzis N and Mikedi K, J Chromatogr B, 1998, 706(2), 245-251.

32. Wu Y J, Cheng Y Y, Zeng S and Ma M M, J Chromatogram B, 2003, 784(2), 219-224.

33. Jones D R, Gorski J C, Hamman M A and Hall S D, J Chromatogr B, 1996, 678, 105-111.

34. Eichhold T H, Greenfield L J, Hoke S H and Wehmeyer K R, J Mass Spectrum., 1997, 32(11), 1205-1211.

35. Vengurlekar S S, Heitkamp J, Mccush F, Velagaleti P R, Brisson J H and Bramer S L, J Pharm Biomed Anal., 2002, 30(1), 113-124.

36. Bolden R D, Hoke S H, Eichhold T H, McCauley-Myers D L and Wehmeyer K R, $J$ Chromatogr B, 2002, 772, 1.

37. Sodhi R A, Chawla J L, Sane R T, IndianDrugs, 1997, 34, 433-436.

38. DiGregorio D M, Harnett H D, Sherma J, Acta Chromatogr., 1999, 9, 72. 


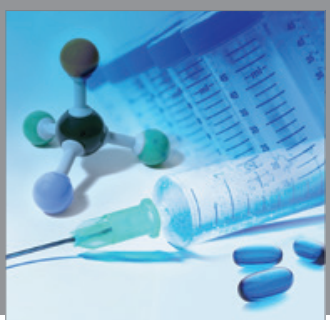

International Journal of

Medicinal Chemistry

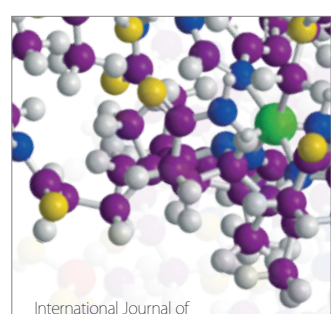

Carbohydrate Chemistry

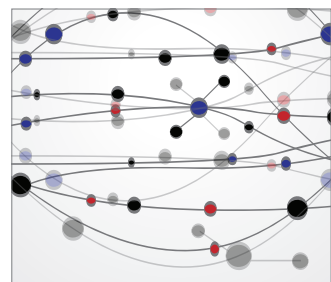

The Scientific World Journal
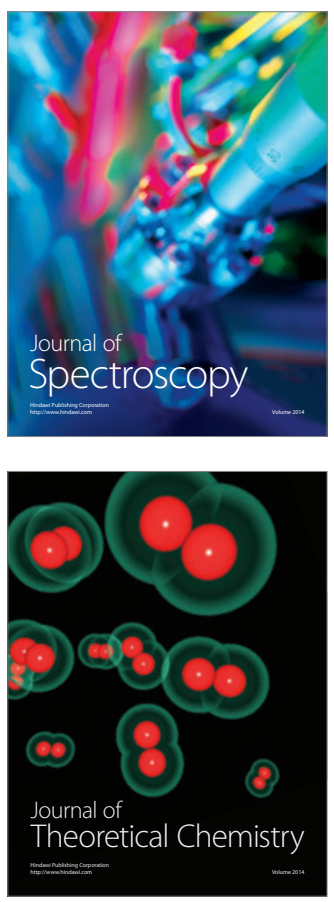
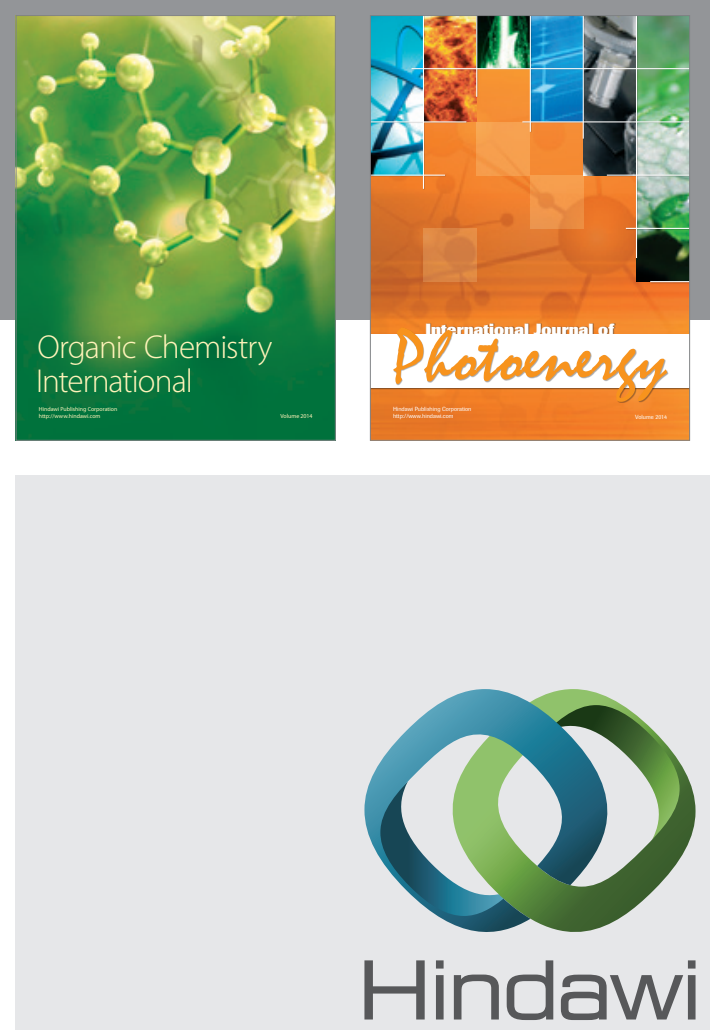

Submit your manuscripts at

http://www.hindawi.com
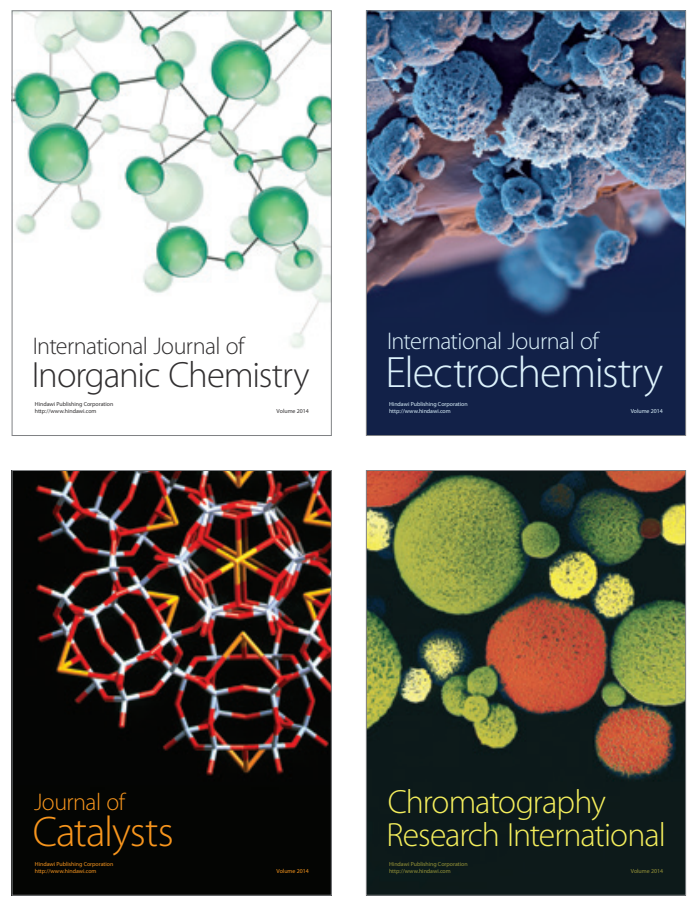
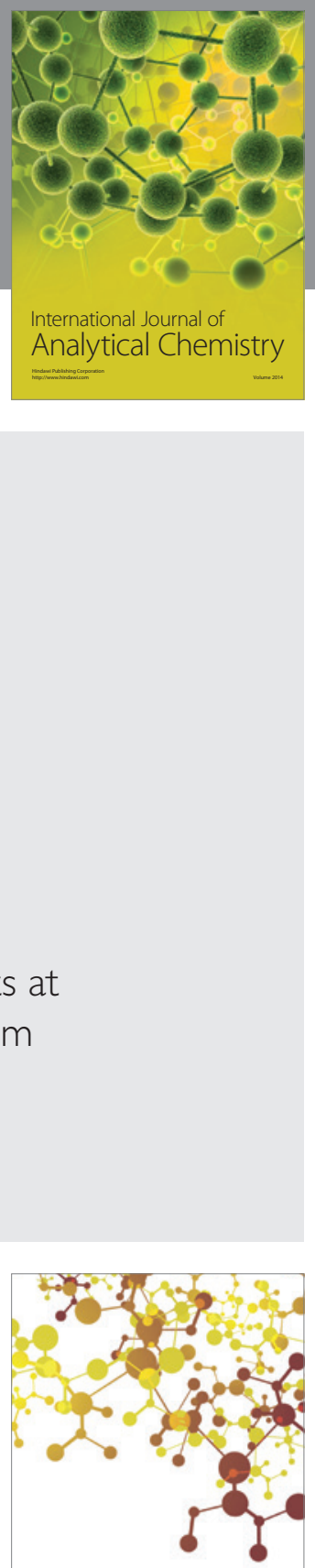

Journal of

Applied Chemistry
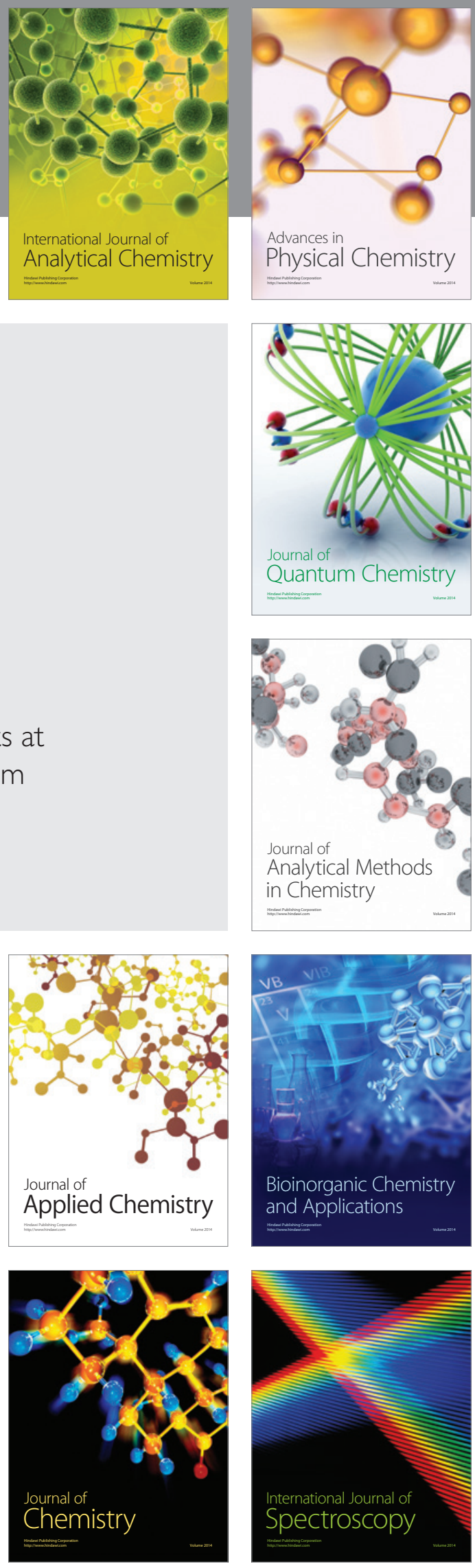